\title{
TEACHERS' PERCEPTION TOWARD THE IMPLEMENTATION OF STUDENTS CENTERED METHOD IN COMPARISON TO TEACHERS CENTERED METHOD IN THE SECONDARY SCHOOL IN RIAU PROVINCE.
}

\section{ABSTARCT}

\author{
Erni \\ English study program \\ Faculty of teachers training and education \\ University of Riau \\ Email: erni.rosda@yahoo.co.id
}

The objective of the study was to know the teachers perception toward the implementation of Students Centered Method ( SCM) in comparison to Teacher Centered Method(TCM) to the secondary school students Riau province. The subject of the study was 28 the secondary school teachers of six regencies in Riau province.

The result of the study indicated that English teachers moderately to highly supported the implementation of SCM in teaching reading. They showed their greater agreement to SCM method than TCM in terms of conditional, conceptual, instructional, and students - learning perspectives. The comparison of teachers' perception toward the implementation of SCM were significantly greater than their perception toward TCM in teaching reading. For classroom assessment, grammar and vocabulary mastery, and content learning for instructional perspectives dimension and memorizing strategy and everyday reading habit for students learning perspectives dimension, teachers showed positive perspective to TCM than to SCM but there was no significant differences on means value of both methods. Lastly, there were no significant differences on teachers perception regarding their, ages, sex, education except for those teaching experiences above 20 years but with no significantly differed on mean value of both .

Keywords: perception, student centered method, teacher centered method

\section{INTRODUCTION}

Reading subject in EFL class shows its beneficial role to students interest and motivation in Riau Province. Base on Competency- Based Curriculum, in teaching English, students are trained in the four language skills; listening, speaking, reading , and writing. Among these four language skill, reading is regarded as the most important skill for learners because it perceived as the key to access knowledge in science and technology. In doing so, SCM still runs in reading class in senior high school as a matter of fact.

Student Centered Method ( SCM) is the teaching procedure that shifts the focus of activity from teacher to students. According to Felder (2012) active learning, cooperative learning, and inductive teaching and learning technique are 
Teachers' Perception Toward the Implementation of Students Centered Method in Comparison to Teachers Centered Method in the Secondary Chool in Riau Province.

parts of Student Centered Method. In Active Learning students solve problems, answer questions, formulate questions of their own, discuss, explain, debate, or brainstorming during class; in cooperative learning students work in team for problems and projects under conditions that assure both positive interdependence and individual accountability; in inductive teaching and learning, students are first presented with challenges ( questions and problems) and learn the course material in the context of addressing the challenges while Inductive learning covers inquirybased learning, case-base instruction, problem-base learning, project-based learning, discovery learning, and just-in-time teaching (Flender, 2012).

Regarding Bloom's Taxonomy ( 1956) and Gardner's theory of multiple intelligences (1983), Students-Centered Method should be integrated to curriculum because it supports students motivation, promotes peer communication, reduces destructive behavior, builds students-centered relationships, promotes discovery/ active learning, and is responsible for one's own learning. SCM can be beneficial for students reading comprehension because it promotes various mode of diverse learning style. The implementation of this method is focused on students needs, abilities, interest, and learning style with teacher as the facilitator in which reading activities acknowledges students' voice as a central to the learning experience (www. Wikimedia.com 2012). In teaching reading comprehension, there are four learning models under SCM used by reading teachers; Active learning, Collaborative Learning, Cooperative Learning, and Problem-Based Learning.

Active learning is defined as any instructional method that engages students actively in the learning process. Bonwell, C.C., and J. A. Eison (1991) noted that active learning requires students to do meaningful learning activities and to think about what they are doing . The activities might include traditional activities such as homework, in practice active learning refers to activities that are introduced into the classroom. Active learning is often contrasted to the traditional lecture or TCM in which students passively receive information from the instructor. (Prince, 2004)

[5] Collaborative learning is all group-based instructional methods, including cooperative learning in which students work together in small groups toward a common goal (Prince, 2004). However, some teachers distinguish between collaborative and cooperative learning as having distinct historical developments and different philosophical roots. In interpretation, the core element of collaborative learning 
Vol 7, No 2, Oktober 2012: 90 - 101

is emphasized more on student interactions rather than on learning as a solitary activity( Bruffee, K. 1995: 12).

[5] Cooperative learning is defined as a structured form of group work where students pursue common goals while being assessed individually ( Lipsey, M.W., and Wilson, D.B., 199: 1181-1209). Cooperative learning has five characteristics ; individual accountability, mutual interdependence, face- to-face interaction, appropriate practice of interpersonal skills, and regular self-assessment of team functioning ( Feden, P., and R. Vogel,2003 and Johnson, D., R., Johnson, and K. Smith, 1998). It focuses more on cooperative incentives than competition to promote learning. In understanding a text, students gain knowledge not only from the teacher but also through cooperation with each other in pairs or in the group.

Problem-based learning (PBL) is an instructional method in which relevant problems are introduced at the beginning of the instruction cycle and used to provide the context and motivation for the learning that follows (Prince H. 2004). PBL can be done in collaborative or cooperative models and involve significant amounts of selfdirected learning.

Based on the observation to the school teachers in Riau Province, TCM is still implemented in teaching reading skill (erni,2019). Most class time is spent by teacher's lecturing where students listen and work individually answering questions while cooperative working is discourage. Teaching reading is aimed at enabling students to pronounce sentence accurately, read loudly, and identify the grammatical rule of language then answer the comprehension questions of text.

There were some factors caused TCM still implemented in the teaching of reading by school teachers in Riau Province. The first factor is dealing with teacher misconception about SCM. Teacher assumed that through SCM they gave up organizational and leadership responsibility completely. Teachers felt that interactive activities were waste of precious time ( Alwasilah, 1997; Exley 2004; Mustafa, 2001). Teachers have to spend more time having activities in which students need to be discussing what they have read. This was seen as a very time consuming activity in which the teachers would rather fill the time with root learning drills of language aspects. In contrast, SCM stimulated learners to learn simultaneously in two ways ; inter-psychological ( between learners ) and intra-psychological ( inside learners) ( Cherry:2012), and socio-cultural theory believes that parents, peer, caregivers and the culture at large were responsible. ( Vygotsky:1978). 
The second factor is dealing with large size of classroom in Riau province. The numbers of class in school were 35 to 40 students with small room volume. This big class inhibited the teachers to create conducive learning community ( Zainil.2005). It also spent more time to rearrange the seat and cause noisy. To emphasize, Stallings and Kaskowitz ( 1974, in Good and Brophy 1977) found that there was positive correlation between student achievement and time spent with teacher in moderate size or large group. This condition made the teachers to teach reading in traditional ways or TCM.

The third factors deals with classroom interaction and atmosphere. The classroom activities of reading were focused on students skills to find main idea, supporting detail, and to comprehend the text or conversation text. The expected students' competency is to be able to comprehend reading text. Very limited discussion on why the writer uses/ utters such words, phrases or sentences to express certain idea. In his study, Soar (1973, Good and Brophy 1977) found that students working alone and independent of a teachers appears to have less than those who work in group. Moreover, they said that classroom activities must be created as interesting as possible to motivate students for higher reading achievement and teachers need to have in-depth knowledge of their subject area to make their teaching meaningful and interesting as well

The fourth factor deals with assessment procedures obligated by the institution in which teacher should gain students score for paper/ pencil as the criterion for the success of students on specific subject course including National Examination even though the ministery of education with his regulation No 047/U/2002, 4 April 2002 Chaper III/ 3 and No. 20 Tahun 2003 Chapter XVI/ 58 - 1 pointed out that classroom assessment should be done in form of authentic assessment or continuous assessment to gain better classroom achievement. The type of Authentic assessment for English language learners are oral interview, story/ text telling, writing samples, projects, experiment/demonstration, constructed/respons items, teacher observations and portfolio( O'Malley and Pierce, 1995) to replace paper/pencil test .

- The implementation of SCM versus TCM in of Riau

The implementation of TCM was not fully TCM because there were also activities for students to discuss and to present on their own idea or argumentation 
Vol 7, No 2, Oktober 2012: 90 - 101

about the text being read. The students not only memorized difficult words, understood grammar, references, punctuation, and answered questions provided by teacher, but also expressed their understanding or critical thinking to the material they read. By TCM , teachers determined all teaching contents and the student just organized the structure of teaching systematically and received of knowledge. This method would ensure the mastery of what is in the text through verbal communication and the teacher will work through the text by providing long series of questions which are associated with the explaining of the text and the teacher is the one who transfers material as figured out by Balitho (1990).

According to Carter and Long ( 1991) this TCM allowed to little opportunities for learners to formulate their own experience and knowledge about the text. Teachers position in TCM does not mean taking over responsibility for students' learning completely on how much the teacher structures or directs learning, but the students need to I have responsibility for working and expanding effort to comprehend new material.

In comparison, SCM as clarified by Vygotsky:1978 that SCM involved a careful coordination between the individual's capacities, abilities, and teacher tendencies and the learning environments in which new information and skill were presented to the community learning (www.wikipedia.com). To conclude, teachers are more like facilitators to clarify, to stimulate, and to promote students' mind and the learners are welcome to give their opinions and suggestions to develop their own responds in understanding the text. The diagram below shows a constant flow of learning, manifests a more independent relationship of the three important elements; material, teacher and students that flows in either way in SCM ( Balitho. 1990) 


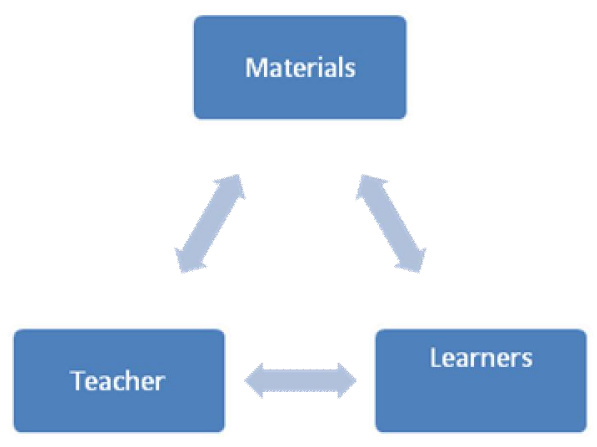

The following table shows two teaching ( SCM and TCM). The role of teacher and students in different teaching method implemented in reading classes are grouped into three learning model ; Teacher Centered (Mass Learning), Learner centered (Individual Learning) and Learner Centered ( Group Learning) as seen in the table below:

Tabel 1. Three Models Of Teaching

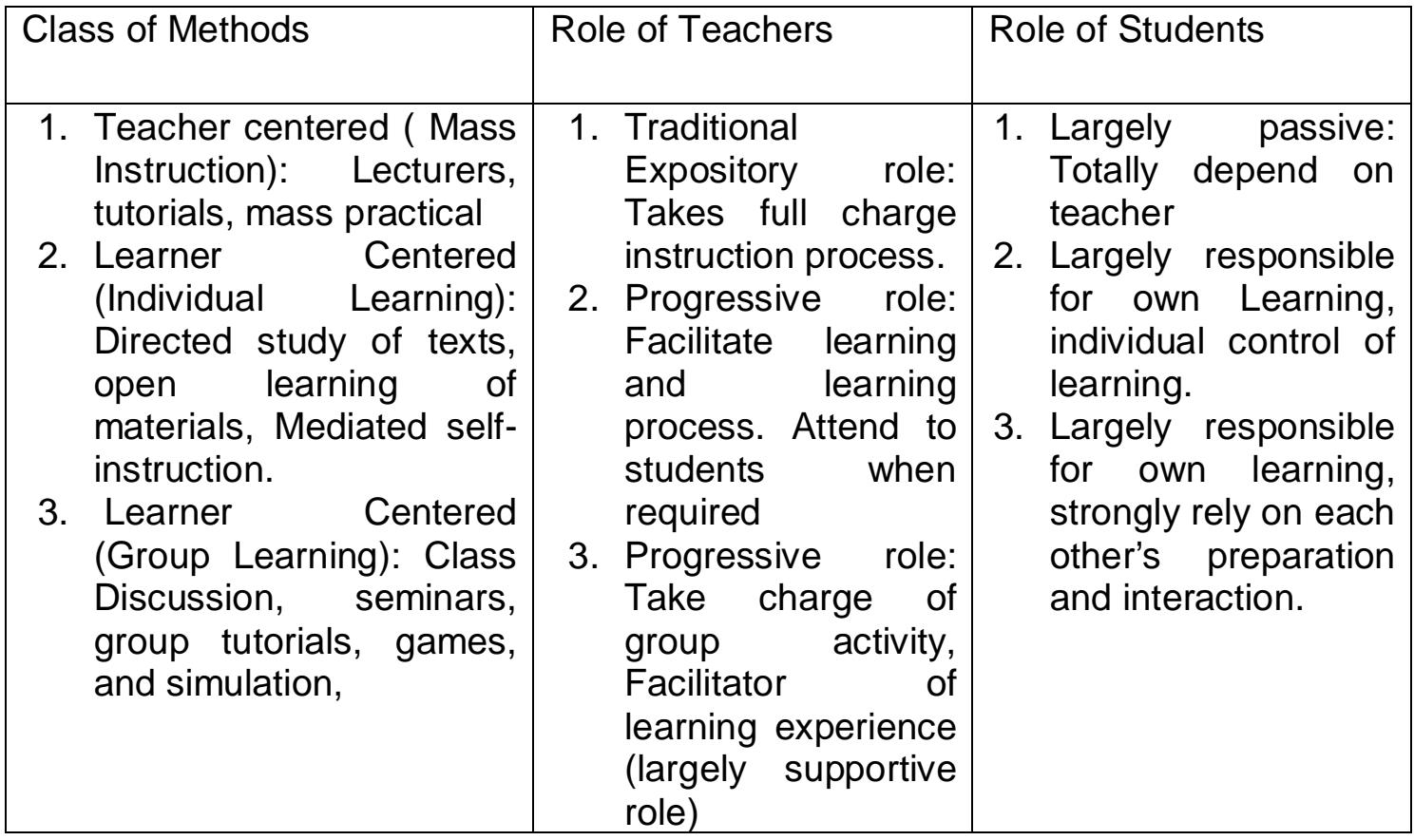

Source: (Ellington, $\mathrm{H}$ and Shirley Earl. 1999)

Many reading methods have been tried to improve students reading comprehension achievement. The education practitioners needs teachers' preparation to provide reading skill instruction and many research has been done to reach better perceptions of teachers regarding the integration of reading instruction into national syllabus and the influence of these variables on their perceptions. Polkinghorne and Marcia (2010) had done descriptive design to 95 
Vol 7, No 2, Oktober 2012: 90 - 101

determine the perceptions of teacher educators responsible for teaching the methods courses to teacher candidates. He found that over half $(58.12 \%)$ responded to the mailed survey showed most $(99,89.1 \%)$ teacher educators agreed or strongly agreed that high school teachers should integrate reading instruction in reading courses, 64 (58.7\%) indicated they disagreed or strongly disagreed that business teachers should be held accountable for teaching reading in EFL class. In conclusion, the majority of teachers had favorable perceptions towards the implementation of SCM and TCM in developing reading skills.

The objectives of this study were to investigate the teachers' perception on the condition, conception, instruction and students learning perspectives toward the implementation of SCM in comparison to TCM in teaching reading with the survey items written in matching pairs as the questionnaire instruments.

Descriptive statistics in form of frequency, percentage and mean scores were used in presenting and answering research questions:

1) How is teachers' condition perspective regarding knowledge, preference , and frequency of use of the implementation SCM and TCM in Competency Based Curriculum.

2) How is teachers' conceptual perspective regarding knowledge, preference ,and frequency use of the implementation SCM and TCM in reading instruction.

3) How is teachers' classroom instruction perspectives of the implementation SCM and TCM.

4) How is teachers' learning dimension perspectives on classroom instruction using SCM and TCM.

\section{METHODS}

The subject of the study were selected from 18 school with 56 total population of ESL reading teacher in Riau Province. They were spread out in 6 Regencies in Riau ; Rohil, Rohul, Inhil. Inhu, Kampar, and Pelalawan. Cluster random sampling technique was done to select students sample (Gay,1987). The size sample of the study were 28 teachers from 12 secondary schools in Riau Province with 2 or 3 school teachers for each school. This research was conducted from January 2012 to April 2012. 
The instrument for this survey research was written questionnaires with pair items for SCM and TCM components that consisted of five sections of Questionnaires designed to gain data about:

1. personal information of the respondents.

2. condition perspective regarding knowledge, preference, and frequency use of the implementation of SCM and TCM in Competency-_Based Curriculum

3. conceptual perspective regarding knowledge, preference, and frequency use of the implementation SCM and TCM in reading instruction

4. teachers' perspectives on classroom instruction in SCM and TCM.

5. teachers' perspectives on students learning strategies in SCM and TCM.

The pilot study was done to get the validity and reliability of the instrument. The content for questionnaire were face validated by the judgment of expert in relevant field and the items content were related to research questions and objectives. During the pilot study, the respondents showed no difficulty in understanding and answering the questions. Dealing with the data for personel information, the extra information were given to validate the data gained. Modification were also made for the demographic respondents. On the part of education, there were minor correction such as teacher adding non degree education not to be placed in the box. The result of pilot study for the reliability index of teacher questionnaires on conceptual perspectives using The Cornbach Alpha Value was found that the correlation coefficient between items with scores from 0,2360 to 0,6126 . The standardized Alpha item is 0,7636 . The number of questionnaires were 16 items. The implication from the observed value indicated that all items used have a high and consistent Cronbach Alpha value. Meanwhile teacher questionnaires on Instructional perspective showed that the correlation coefficient between items with score from 0.3148 to 0,5172 . The standardized Alpha item as 0,7148 . The number of questionnaires were 22 items. The implication from the observed value indicated that all items used have a high and consistent Cronbach Alpha value. Continuously, questionnaires for teacher perception on students learning perspective showed that the correlation coefficient between items with score from 0,2524 to 0,5365 . The standardized Alpha item is 0,6334 . The number of questionnaires were 22 items. The implication from the observed value indicated that all items are reliable. 
Vol 7, No 2, Oktober 2012: 90 - 101

The result of data collection were used to interpret level of mean scores. To do so, the researcher looked at the frequency, percentage and mean score directly from the 5 point Likert Scale. The researcher also look at the mean score and level category adopted from Rahaya and Salbiah (1996) as the following:.

Tabel 3. Interpretation of mean scores variables

\begin{tabular}{|l|l|}
\hline $1.0-1.80$ & Very low \\
$1.81-2.60$ & Low \\
$2.61-3.40$ & Moderate \\
$3.41-4.20$ & High \\
$4.21-5.0$ & Very high \\
\hline
\end{tabular}

The researcher coded all questionnaire item as follows: Strongly Agree $(S A)=$ 5 , Agree $(A)=4$, Undecided $(U)=3$, Disagree $(D)=2$, Strongly Disagree $(S D)=1$. The negative items (for conceptual perspectives) were scaled as reverse as the following manner: $5=1,4=2,3=3,2=4,1=5$. All negatives items were summed up to give overall positive scale.

\section{RESULT AND DISCUSSION}

a. Profile of teacher respondents.

Total respondents were 28 respondents. The research findings of this quantitative data on the analysis of questionnaire items were presented in the following :

Tabel 6. Profile of teacher respondents

\begin{tabular}{|l|l|l|l|l|}
\hline Demography & N & Respondents & Frequency & $\%$ \\
\hline Sex & 28 & Male & 2 & 7,10 \\
& & Female & 26 & 92,90 \\
\hline Degree Major & 28 & Graduate & 6 & 21,43 \\
\hline & & Undergraduate & 22 & 78,57 \\
\hline Teaching & 28 & $1-5$ years & 8 & 28,57 \\
Experience & & $6-12$ years & 6 & 21,43 \\
& & $11-15$ years & 6 & 21,43 \\
& & $16-20$ years & 4 & 14,29 \\
& & $>20$ years & 4 & 14,29 \\
\hline Attended Course & 28 & Yes & 17 & 60,71 \\
& & No & 11 & 39,29 \\
\hline
\end{tabular}

b. Descriptive Statistical Analysis - Teacher's Questionnaire 
Teachers' Perception Toward the Implementation of Students Centered Method in Comparison to Teachers Centered Method in the Secondary Chool in Riau Province.

(Erni)

1. Teachers' responses on condition perspective ( regarding understanding, preference, and frequent use) to SCM compared with TCM as a powerful method for Competency-based curriculum (item 9-16, ) showed that the mean score of SCM 3,87 was higher than those of TCM 3.62 except for item no 14. There was no significant difference on condition in Competency-based curriculum between these two methods. In short, there were no wide different of mean scores between SCM and TCM.

2. The teachers' responses on conceptual perspective (understanding, preference, and frequent use: item 1-8) of SCM were greatly in positive condition with all mean value 4,00 or high. Meanwhile the teacher group's responses to condition items ( understanding, preference, and frequent use) for the TCM were high, moderately, and low rating with mean value 3,21. There was significantly larger values for the implementation SCM in teaching reading with critical T test significant was $<.001$. It showed that teachers' perception on condition dimension of SCM were significantly higher than those of TCM.

3. Teachers responses on instructional perspective, all mean score of SCM was higher than those of TCM. The mean scores of SCM was 4,12 whereas the mean score of TCM was 3.38 and both were in high to moderate level. In detail, the mean scores for instruction group items for developing reading skills (item no 1), interpreting text ( item no 3), argumentation (item no 5), Contextual meaning ( item no 7), drawing conclusion ( item no 9) of SCM were significantly higher than those of TCM. The mean scores for items on achievement paper/pencil test (item no 11), grammar and vocabulary mastery (item no 13), content learning (item no 15) of SCM were lower than those of TCM. The range of the mean scores was 2.65 - 2.96 for SCM whereas for TCM 3.78 - 4.10 and both were in moderate to high level. Content learning ( item no 18) and portfolio assessment ( item no 22) SCM mean score was significantly higher than those of TCM ( 4.20 for SCM -2.98 for TCM).

4. Teachers responses to students learning perspective the mean scores of SCM was higher than those of TCM it term of reading authentic text, questioning, students responsibility, social development, persuasion, classroom interaction, reading for pleasure. The mean values was in very high level $>4.20$ while for TCM in low level $<260$. It showed that teacher perception on students learning dimension 
Vol 7, No 2, Oktober 2012: $90-101$

on SCM significantly higher when compared with TCM except for memorizing strategy and everyday reading habit, TCM was dominant.

\section{CONCLUSION}

In general, the positive perceptions showed by the English teachers toward the implementation of Student-Centered Method in teaching reading in high school in Riau Province. The comparison of teachers' perception toward the implementation of Student-Centered Method was significantly greater than their perception toward Teacher -Centered Method in teaching reading except for classroom assessment, grammar and vocabulary mastery and content learning for instructional perspectives and memorizing strategy and everyday reading habit for students learning perspectives with no significantly differences of both methods. In addition, there were no significant differences on teachers perception regarding their teaching experience, ages, sex, and educational background.

\section{REFERENCES}

Bruffee, K. "Sharing Our Toys: Cooperative Learning Versus Collaborative Learning," Change, January/February, 1995, p. 12.

Bloom, Benjamin.1956. Taxonomy of Educational Objectives: The Clasification of Educational Goal. Susan Faeuer Company.Inc

Balitho,R.1990. Teaching Methodology for the Nineties : An External Triangle In Sarinee Avinon, ( ed) Roles of teachers, Learners, and teaching Materials .

Bloom, Benjamin.1956. Taxonomy of Educational Objectives: The classification of educational goals. Susan Tauer Company, Inc.

Carter, R and Long. M.N. 1991. Teaching Literature. Hongkong: Longman.

Cherry, Kendra. What is Socio-cultural Theory. www.sim.edu.sg/JOCE [20 March 2012 ]

Ellington, H. and Shirley, Earl. 1999. Facilitating Student Learning: A Practical Guide for tertiary-level teachers. Skudai:Universiti Teknologi Malaysia.

Gardner, H. 1983. Frames of Mind: The Theory of multiple Intelligences. New York: Basic Books.

Gardner, H. 1983. Frames of Mind: The Theory of Multiple Intelligences. New York: Basic Books.

Lipsey, M.W., and Wilson, D.B., "The Efficacy of Psychological, Educational and Behavioral Treatment: Confirmation from Meta- Analysis," American Psychology, 1993: Vol. 12 p. 1181-1209

Johnson, D., R., Johnson, and K. Smith. 1998. Active Learning: Cooperation in the College Classroom, 2nd ed., Interaction Book Co., Edina, MN. 
Flender, P., and R. Vogel. 2003. Methods of Teaching: Applying Cognitive Science to Promote Student Learning, McGraw Hill Higher Education.

O'Malley.J.Michele and pierce, Lorraine Valdez .1995. Authentic Assessment for English language Learners: Practical Approach for teachers. Ontario:AdisonWesley Publishing Company.

Bonwell, C.C., and J. A. Eison,1991. "Active Learning: Creating Excitement in the Classroom," ASHEERIC Higher Education Report No. 1, George Washington University, Washington, DC. 1991.

Online Collaborative Learning in Higher Education, <http://clp. cqu.edu.au/glossary.htm>, accessed 12/3/2003.

Millis, B., and P. Cottell, Jr. 1998. "Cooperative Learning for Higher Education Faculty," American Council on Education, ORYX Press.

Prince,M.J. 2004. Does Active learning Work?, “ A Review of the Research”. J.Eng, Ed., 93 (3),223, < http://www.nesu.edu/felder-public/papers/Prince_al.,Pdf>

R.M Felder (2012) Student-Centered Teaching and Learning http://www4.ncsu.edu/unity/lockers/usesrs//felder/public/student-centered teaching.

Felder, RM and Bullard, L.G. 2007. A Student Centered Approach to teaching: Materials and Energy Balances. Chem.Engr. Education. Vol 41.No.3, Summer. ChE Division of ASEE.

Smith, B., and J. MacGregor, "What is Collaborative Learning?, http://www.nesu.edu/felder-public/papers/Prince_al.,Pdf>

Vygotsky. L.S. 1978. Mind and Society: The development of higher psychological process. Cambridge, M.A. Harvard University Press.

Zainil.2005. Motivating the Reluctant language learner. Padati-Web Journal. http://www.depdiknas.go.id ( September 20th,2011) 